\title{
APPLICATION OF THE "STYLES" PRODUCTIVE PROJECT IN THE ACHIEVEMENT OF PERSONAL AESTHETIC CAPABILITIES IN CETPRO JESÚS OROPEZA CHONTA STUDENTS IN COVID-19 PANDEMIC
}

\section{Torres Alvarez, Ysabel Fabiola}

Cesar Vallejo University

\section{ABSTRACT}

The objective of the research was to determine the influence of the application of the productive project "Styles" on the achievement of the personal aesthetic capabilities of the Module hairstyles in students of CETPRO Jesús Oropeza Chonta, SJL 2020. It was a quantitative approach research, of pre-experimental design, worked with an experimental group, was of applied type because it focused on the search for solving the problem in developing capacities for pre-professional practice to a sample of 15 students to whom a rubric was applied as a pre/post test instrument that was validated and subjected to a reliability whose result was 0.778 (acceptable) according to the Cronbach Alpha. Descriptive results showed that $60 \%$ of students were placed at the achievement level and statistical test performed using the Wilcoxon non-parametric test, as they are related groups (pre and post) because the data were not distributed as normal, concluding that the application of the productive project "Styles" in achieving the personal aesthetic capabilities of the Module hairstyles in CETPRO students.

Keywords: Productive project, personal aesthetics, CETPRO.

Article Received: 18 October 2020, Revised: 3 November 2020, Accepted: 24 December 2020

\section{INTRODUCTION}

The globalization of the economy, afected by COVID19 and the technologic advances, have changed the present job market since we can view how people generate their own jobs. On the same spirit, the United Nations (2015), following the 2030 Agenda, decided to increment the number of young and adult people that meet the necessary standars (technical and proffesional) in order to auto generate jobs with decent work enviroments and entrepreneurship.

The UNESCO (2016) using the SDG (Sustainable Development Goals) as guide, four 2030 Agenda objectives and considering the context of the job markets in Latin America change rapidly; the unemployment raises primordialy between the youth; the aging of the working force in various countries; internal/external migration and technological advances mean that most countries are confronted with the need for people to obtain skills, knowledge and aptitudes necessary for decent work and to have an entrepreneurial initiative in life that respond to their needs and acquire new ones of self-employment.

The CETPRO Jesús Oropeza Chonta is located in an area of extreme poverty with a population that carries out economic activities of ambulatory commerce (it's a human settlement of extreme poverty), where they work to be able to subsist and live day to day; where many of the young people who graduate from secondary school do not have the resources to pay for private universities or other institutes where they acquire technical or professional careers; In this sense, due to their extreme poverty, young people come to the CETPRO Jesús Oropeza Chonta in their jurisdiction in search of improvement and to be able to forge a future, studying technical careers of one year and then inserting themselves in the work environment. The CETPRO offers, in three shifts, technical careers such as: Arts and Crafts, Gastronomy, Personal Aesthetics, Textiles and 
Apparel, Electricity and Electronics, Computing, which are taught through modules that last two to three months; modules conducive to employability and entrepreneurship where the student can generate selfemployment in their locality. In this sense, in coherence with the needs of the students of personal aesthetics who carry the Hairstyles Module, a productive project was applied with them with the aim of developing their skills acquired in the aforementioned Module and being able to have $30 \%$ of practices as established to obtain their certification of the modules and to be able to perform in a dependent or independent manner.

For the development of the study, the General Objective was projected as it follows: Determine the influence of the application of the productive project "Styles" in the achievement of the Personal Aesthetic capacities of the Hairstyles Module in students of the CETPRO Jesús Oropeza Chonta, SJL - 2020. Specific Objectives: (1) determine the influence of the application of the productive project "Styles" in the achievement of the capacities of simple hairstyles in students of the CETPRO Jesús Oropeza Chonta, SJL 2020; (2) determine the influence of the application of the productive project "Styles" in the achievement of the capacities of stylized hairstyles in students of the CETPRO Jesús Oropeza Chonta, SJL - 2020; and, (3) Determine the influence of the application of the productive project "Styles" in the achievement of the capacities of hairstyles with brushing in students of the CETPRO Jesús Oropeza Chonta, SJL - 2020.

It was proposed as General Hypothesis: The productive project "Styles" positively influences the achievement of personal aesthetic abilities of the Hairstyles Module in CETPRO students Jesús Oropeza Chonta, SJL - 2020. The Specific Hypotheses were: (1)
The productive project "Styles" positively influences the achievement of the abilities of simple hairstyles in CETPRO students Jesús Oropeza Chonta, SJL - 2020; (2) The productive project "Styles" positively influences the achievement of the abilities of stylized hairstyles in CETPRO students Jesús Oropeza Chonta, SJL - 2020; and, (3) The "Styles" productive project positively influences the achievement of brushing hairstyles skills in CETPRO students Jesús Oropeza Chonta, SJL - 2020.

\section{MATERIALS AND METHODS \\ Type of Research}

Ellemers (2003) It was a quantitative approach research because data collection and analysis was carried out to test hypotheses (Sánchez, Reyes \& Mejía). It was of an applied type because it sought resources for applying the knowledge derived in basic research (Cazau, 2006). A productive project was developed that contributed to the development of the students' personal aesthetic abilities. Likewise, the Concytec technicians (2019, Art. 5) determined that applied research is carried out to achieve new knowledge, leading mainly towards a specific practical objective. In accordance, Reyes (2019) mentioned that an investigation is of an applied type because it was oriented to the solution of a practical problem.

\subsubsection{Research Design}

The research was a pre-experimental design with measurement before and after (Hernández, Fernández \& Baptista, 2014) they call the experiments intervention studies, because a researcher generates a situation to try to explain how it affects those who participate in it compared to those who do not. It is possible to experiment with human beings, living beings and certain objects. Experiments manipulate 
treatments, stimuli, influences or interventions (independent variables) to observe their effects on other variables (dependant) in a control situation Gareis (2007).

The scheme is:

\begin{tabular}{|c|c|c|}
\hline \multicolumn{3}{|c|}{$\mathrm{GE}$} \\
\hline $\mathrm{O}_{1}$ & $X$ & $\mathrm{O}_{2}$ \\
\hline
\end{tabular}

Where:

$$
\begin{aligned}
\mathrm{GE} & =\text { Experimental group } \\
\mathrm{O} 1 & =\text { Pre Test (rubric implementation }
\end{aligned}
$$

before)

after)

$\mathrm{O} 2=$ Post Test (rubric implementation

$\mathrm{X}=$ Treatment (implementation of the productive project)

\subsection{Variables and operationalization}

\subsubsection{Independent variable: Productive project} "styles"

According to Kerlinger (1988, p.42), it is the variable that the researcher hypothetically assumes as the cause of the dependent variabl. For the present investigation the IV was the productive project "Styles". The independent variable was manipulated by applying the productive project.

\subsubsection{Dependent variable: Personal aesthetics}

\section{Conceptual definition}

According to Kerlinger (1988, p.42), the dependent variable constitutes the effects of the independent variable. In the present work it was considered as DV: Personal aesthetics; which refers to personal appearance and presentation.

The professional of this career is trained to exercise skills related to skin care, manicure, pedicure, cutting techniques, hairstyles, dyeing, extensions, hair treatments; makeup, waxing, among other functions related to personal care (RVM N $\mathrm{N}^{\circ} 178-2018$ MINEDU)

Operational definition

The personal aesthetic variable was operationalized taking into consideration the National Catalog of the training offer in Productive Technical Education and Higher Technological Education, approved with the RVM $\mathrm{N}^{\circ} 178-2018-\mathrm{MINEDU}$. Likewise, the Curricular Programming of the specialty approved by the CETPRO Jesús Oropeza Chonta was considered. The adaptation was made for the dimensions and indicators that were input for the data collection instrument (rubric). The dimensions were: simple hairstyles, stylized hairstyles, and brushing hairstyles (see Annex 2).

\subsection{Population, sample, sampling and unit of analysis}

\subsubsection{Population}

According to Hernández, et al (2014, p. 174) he defines it as the total phenomenon to analyze where the population units common peculiarities. The population amounted to 45 students of the specialty of personal aesthetics the three shifts: morning, afternoon and night.

\subsubsection{Sample}

The sample, according to Hernández, et al., (2014) are components that are defined by certain peculiarities of a representative need. The sample was selected for convenience for the purpose of the research and there were 15 students from the "hairstyles" module of the morning shift.

\subsubsection{Sampling}

Sampling refers to the set of operations that are carried out to study the distribution of certain characteristics in the totality of a population called a sample (Sánchez, Reyes \& Mejía). The sampling was 
non-probabilistic of an intentional type, for the convenience of the proposed objective, considering all the students of the module.

\subsubsection{Unit of analysis}

The units of analysis are characterized by attributes or characteristics that differentiate one from another according to some criteria (Sánchez, Reyes \& Mejía). The unit of analysis is represented by each of the students in the sample.

\subsection{Research technique and instrument}

\subsubsection{Technique}

For Sánchez and Reyes (2015, p 56) they are procedures and rules that allow establishing the relationship with the objective or subject of the study. The technique used was observation because the capabilities established in the measuring instrument were observed.

\subsubsection{Instrument}

They are means to proceed to collect data that are required according to the objectives and research hypotheses (Hernández, et al., 2014, p. 199). In the present investigation, the information was collected through a rubric (See Annex 3 and its technical sheet Annex 5).

\subsubsection{Instrument validity}

Validity is considered as the degree to which an instrument measures the objective it seeks to measure; In this sense, it is important that it be reliable and legal (Hernández et al. 2014). In the study, before applying the rubric, its content validity was carried out, whose qualification for each of the items was applicable, (See Annex 6) and the content validity through expert judgment

\subsubsection{Instrument reliability}

It was applied with the purpose of verifying if the instrument produces congruent results when it is applied for the second time in conditions that are most similar to the initial one (Sánchez, Reyes and Mejía, 2018, p. 36). Because it is an ordinal measurement instrument (with three options), Cronbach's alpha coefficient was applied. A group of 10 students from the morning shift of CETPRO Jesús Oropeza Chonta, SJL - 2020 was attended. The result of the application was equal to 0.78 , which represents an acceptable reliability (Sánchez, Reyes and Mejía, 2018), (see Annex 7).

\subsection{Procedures}

The investigation began by detecting the problem, the objectives were determined and the methodology was established with the support of the advisor. Then, the application authorization from the CETPRO authorities and the consent of the students were requested. The productive project was planned, organized and executed in coordination with the students; First, the pre-test (rubric) was applied, followed by the application of the sessions established in the project through synchronous training; that is, a teaching-learning in the same time and virtual space with the student through video calls, web camera; as well as asynchronous training with reinforcement videos (RVM N ${ }^{\circ}$ 087-2020-Minedu). In the third moment, the post test (rubric) was applied to establish the results before and after regarding the capacities worked. It should be noted that the instrument was developed based on the operationalization carried out, the dimensions and indicators of which were adapted from the National Catalog of the training offer in Productive Technical and Higher Technological Education, approved with RVM No. 178-2018- 
MINEDU and Programming Curriculum of the specialty approved by CETPRO.

\subsection{Data analysis method}

For data processing and statistical analysis, after applying the pre / post, the descriptive statistics were developed to determine the frequencies and percentages using the SPSS version 23 software. For the inferential analysis, the normality test was applied first. of data that determined a non-normal distribution and with this result it was established to use the wilcoxon test because they are correlated samples Andersen (2010).

The formula of the statistic to be used is the following:

$$
Z=\frac{S_{+}-n(n+1) / 4}{\sqrt{n(n+1)(2 n+1) / 24}}
$$

S $\quad=$ Sum of ranges of positive differences between data

Aldefer (1987) To determine the level obtained by each student according to the application of the rubric and according to the qualitative measurement established: Poor (1); Regular (2) and Satisfactory (3) the following levels and ranges were determined: Start (12 - 20); Process (21 - 28) and Achievement (29 $-36)$.

\subsection{Ethical aspects}

In the present investigation, the authors who were cited and referenced according to the APA standards (Moreno \& Carrillo, 2019) were respected. Likewise, the corresponding permits were obtained from the institution's authorities and informed consent from the students.

\section{RESULTS}

\section{Descriptive analysis}

\section{Table 1}

Where:

$\mathrm{n} \quad=$ Sample size

Comparative table in the achievement of personal aesthetic abilities in the pre and post test

\begin{tabular}{llccc}
\hline & & \multicolumn{2}{c}{ GE } \\
\hline Personal aesthetics & Start & f & 6 & 2 \\
& & $\%$ & $40,0 \%$ & $13,3 \%$ \\
& Process & $\mathrm{f}$ & 7 & 4 \\
& & $\%$ & $46,7 \%$ & $26,7 \%$ \\
& Achievement & $\mathrm{f}$ & 2 & 9 \\
Total & & $\%$ & $13,3 \%$ & $60,0 \%$ \\
& & $\mathrm{f}$ & 15 & 15 \\
& & $\%$ & $100,0 \%$ & $100,0 \%$ \\
\hline
\end{tabular}

Figure 1

Achievements obtained in personal aesthetics abilities during the pre-test and post-test 


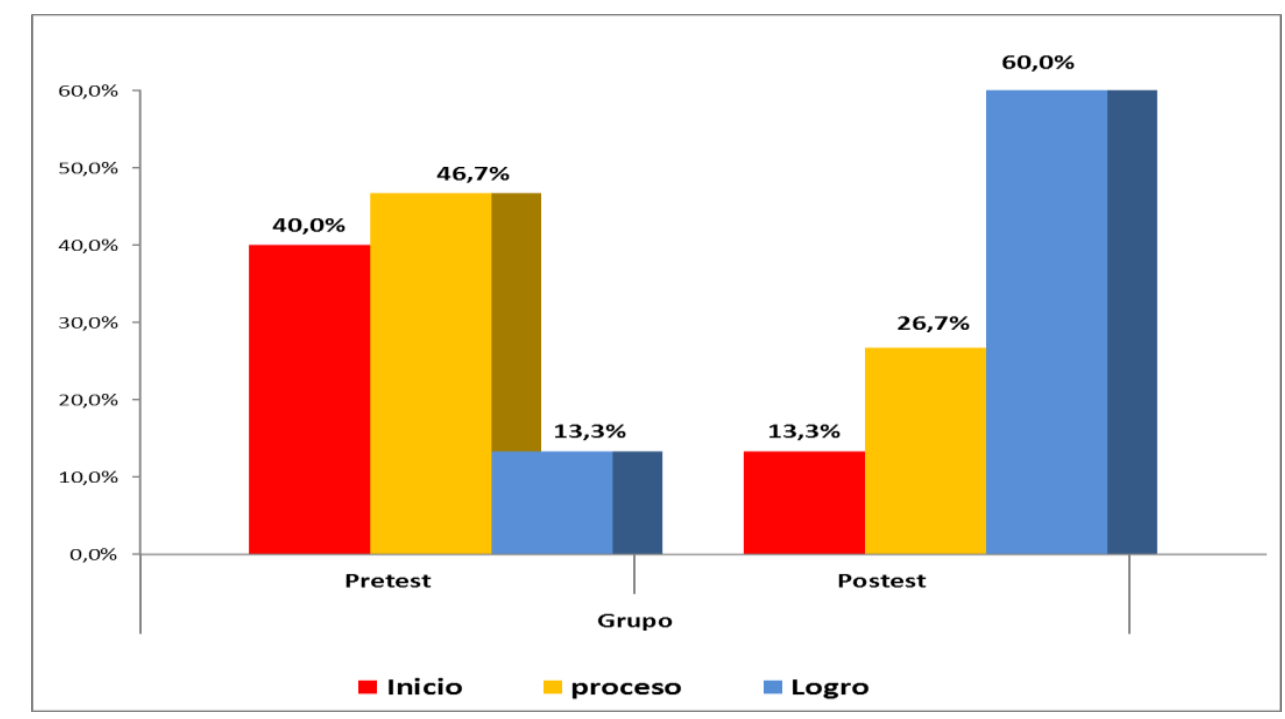

\section{Table 2}

Comparison table in the achievement of simple hairstyles abilities in pre and post test

\begin{tabular}{llccc}
\hline & & \multicolumn{2}{c}{ GE } \\
\hline Simple hairstyles & Start & $\mathrm{f}$ & pre test & Post test \\
& & $\%$ & $53,3 \%$ & 3 \\
& Process & $\mathrm{f}$ & 5 & $20,0 \%$ \\
& & $\%$ & $33,3 \%$ & $26,7 \%$ \\
& Achievement & $\mathrm{f}$ & 2 & 8 \\
Total & & $\%$ & $13,3 \%$ & $53,3 \%$ \\
\cline { 3 - 4 } & & $\mathrm{f}$ & 15 & 15 \\
& & $\%$ & $100,0 \%$ & $100,0 \%$ \\
\hline
\end{tabular}

Figure 2

Achievements obtained in the capabilities of simple hairstyles in pre test and post test 


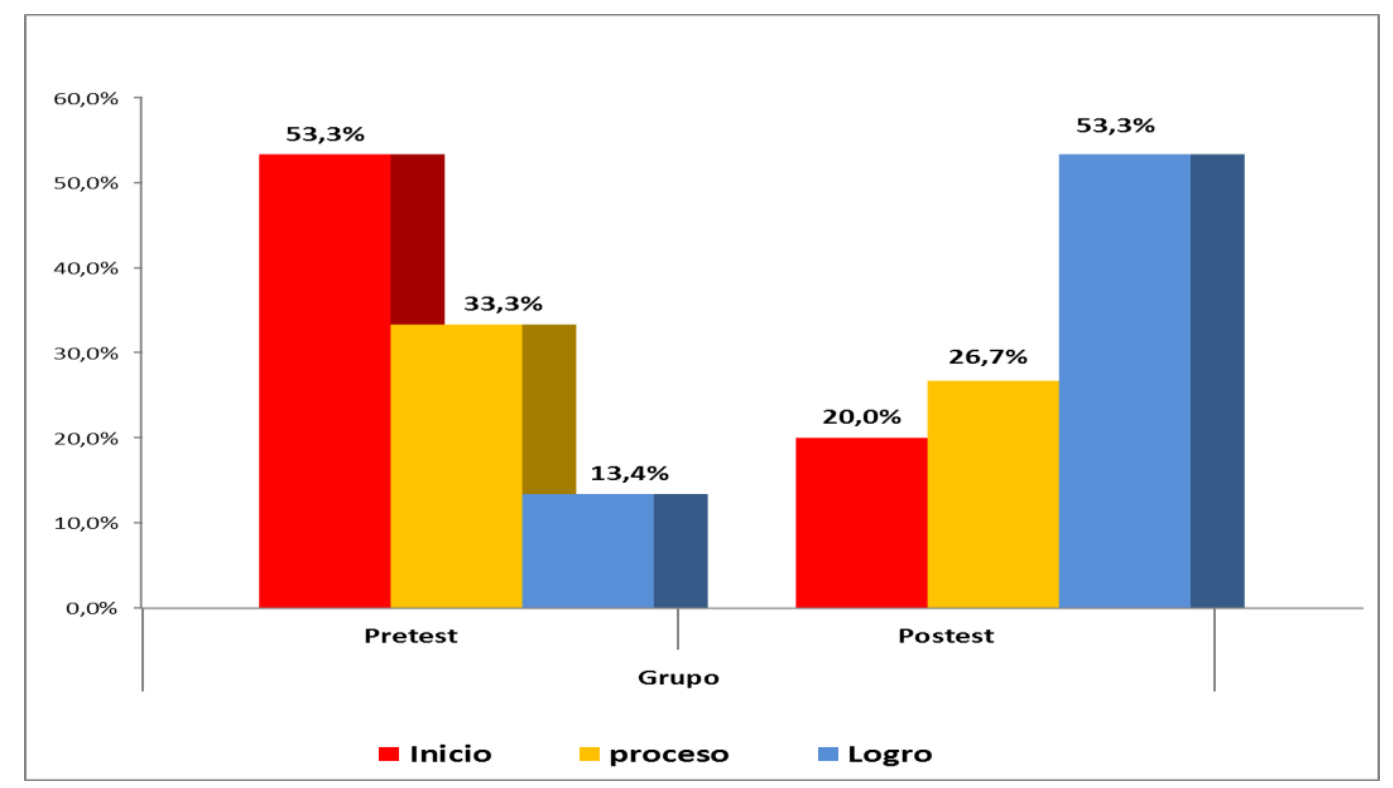

\section{Table 3}

Comparison table in the achievement of stylized hairstyles abilities in the pre and post test

\begin{tabular}{llccc}
\hline & & \multicolumn{2}{c}{ GE } \\
& & & pre test & Post test \\
\hline Stylized hairstyles & Start & $\mathrm{f}$ & 7 & 4 \\
& & $\%$ & $46,7 \%$ & $26,7 \%$ \\
& Process & $\mathrm{f}$ & 6 & 3 \\
& & $\%$ & $40,0 \%$ & $20,0 \%$ \\
& Achievement & $\mathrm{f}$ & 2 & 8 \\
Total & & $\%$ & $13,3 \%$ & $53,3 \%$ \\
\cline { 3 - 5 } & & $\%$ & 15 & 15 \\
& & $\%$ & $100,0 \%$ & $100,0 \%$ \\
\hline
\end{tabular}

Figure 3

Achievements obtained in the abilities of stylized hairstyles in pre test and post test 


\section{Table 4}

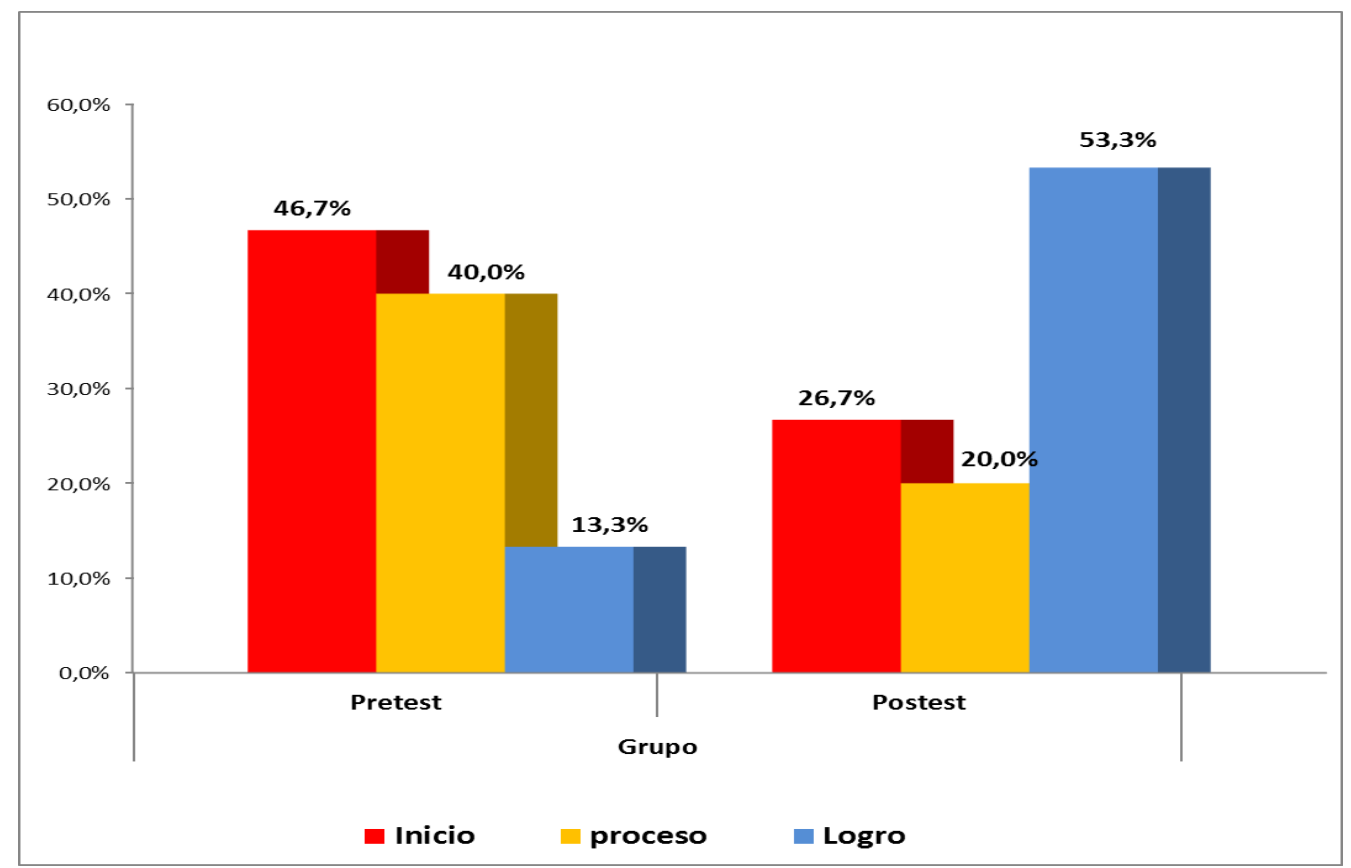

Comparative table in the achievement of combing abilities with brushing in pre and post test

\begin{tabular}{llccc}
\hline & & \multicolumn{2}{c}{ GE } \\
& & & pre test & Post test \\
\hline Brushed hairstyles & Start & $\mathrm{f}$ & 6 & 3 \\
& & $\%$ & $40,0 \%$ & $20,0 \%$ \\
& Process & $\mathrm{f}$ & 8 & 2 \\
& & $\%$ & $53,3 \%$ & $13,3 \%$ \\
& Achievement & $\mathrm{f}$ & 1 & 10 \\
Total & & $\%$ & $6,7 \%$ & $66,7 \%$ \\
& & $\mathrm{~F}$ & 15 & 15 \\
& & $\%$ & $100,0 \%$ & $100,0 \%$ \\
\hline
\end{tabular}

\section{Figure 4}

Achievements obtained in the abilities of hairstyles with brushing during the pre and post test 


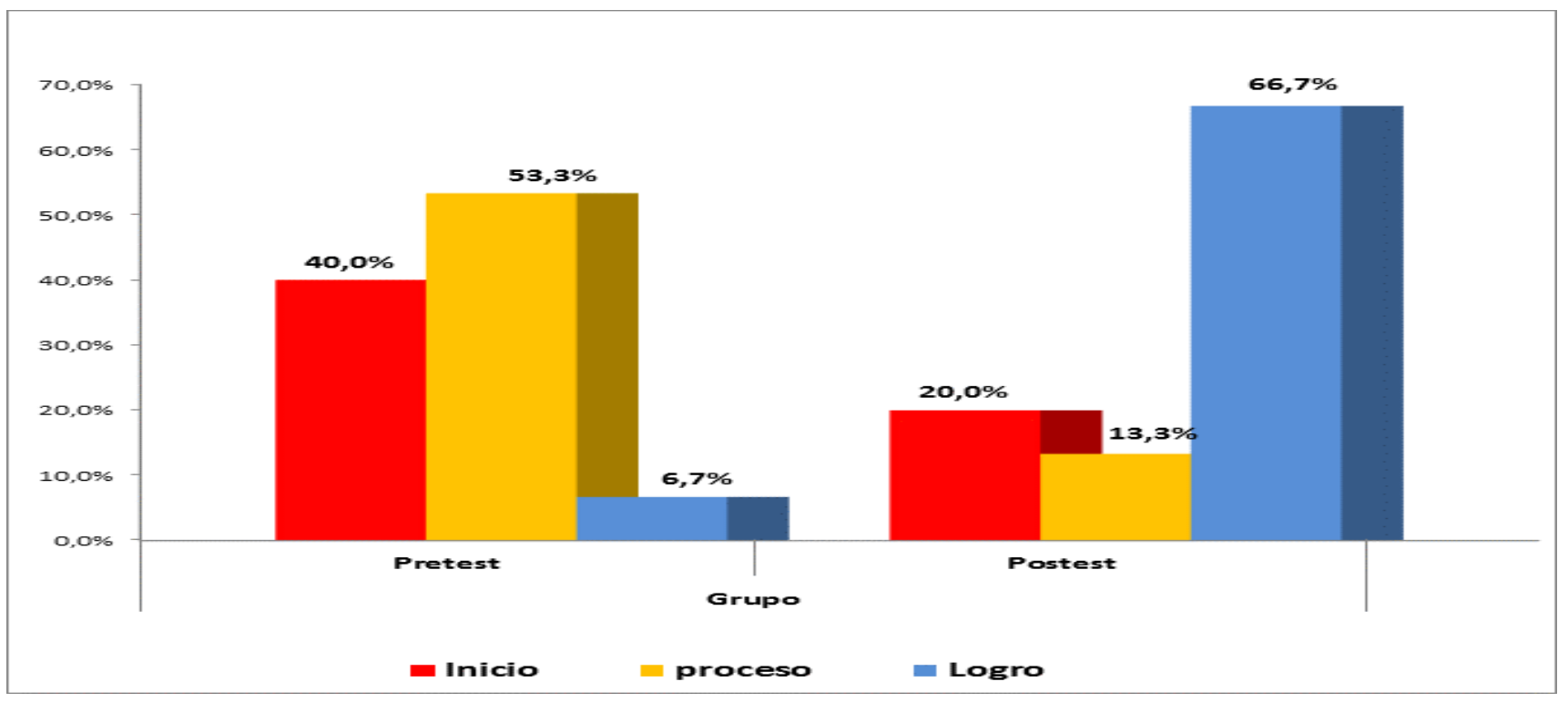

\subsection{Normality Test Shapiro - Wilk Test}

The Shapiro-Wilk test was applied, it is used to contrast the distribution of the data with small samples $\mathrm{n}<50$, because shapiro-Wilk data is less than 50 .

\section{Table 5}

Normality Test Results

\begin{tabular}{lccc}
\hline & \multicolumn{3}{c}{ Shapiro-Wilk } \\
& Estadistic & gl & Sig. \\
\hline $\begin{array}{l}\text { Pre test } \\
\text { V. Personal aesthetics }\end{array}$ &, 798 & 15 &, 000 \\
Simple hairstyles &, 755 & 15 &, 001 \\
Stylized hairstyles &, 783 & 15 &, 002 \\
Brushed hairstyles &, 766 & 15 &, 001 \\
Post test & & & \\
V: Personal aesthetics &, 716 & 15 &, 000 \\
Simple hairstyles &, 749 & 15 &, 001 \\
Stylized hairstyles &, 734 & 15 &, 001 \\
Brushed hairstyles &, 649 & 15 &, 000 \\
\hline
\end{tabular}

Source SPSS vr 25.

\subsection{Inferential analysis General Hypothesis Contrast}

$\mathrm{H}_{0}(\mathrm{Me} 1=\mathrm{Me} 2)$ : The "Styles" productive project does not significantly influence the achievement of personal aesthetic abilities of the Hairstyles Module in students. 
$\mathrm{H}_{1}(\mathrm{Me} 1 \neq \mathrm{me} 2)$ : The "Styles" productive project has a significant influence on the achievement of personal aesthetic abilities of the Hairstyles Module in students.

Table 6

Wilcoxon signed rank test to test the general hypothesis according to rank and contrast statistics

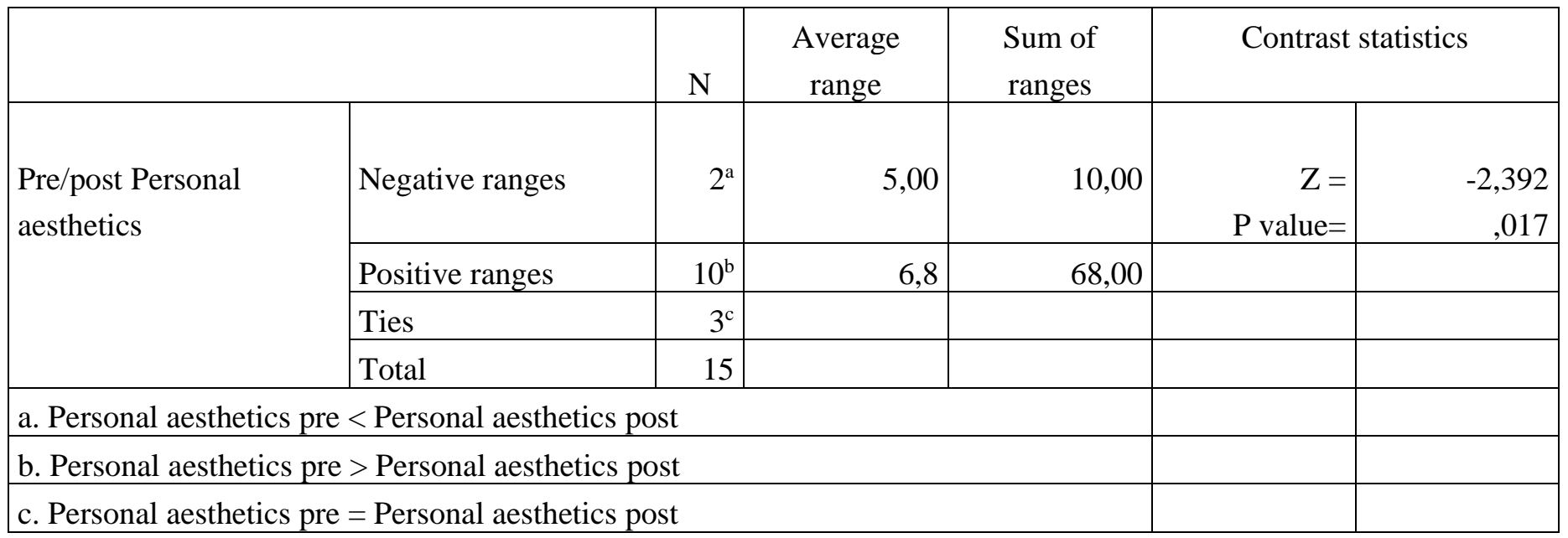

It is observed that after applying the productive project; The 15 students in the sample obtained positive advances in the achievement of personal aesthetic abilities, according to positive ranges (10) with respect to the two negative and three ties. Likewise, the value of the $\mathrm{Z}$ statistic $=-2.392<1.96$ and whose $p$ value $=0.017$, which is $<0.05$, confirm that there are statistically significant differences between the pre-test and post-test data where better levels were obtained. of achievement; Also, an increase in the median of the post-test data compared to the pre-test is observed in the figure.
Consequently: The "Styles" production project has a significant influence on the achievement of personal aesthetic capabilities of the Hairstyles Module.

\section{Specific Hypothesis Contrast 1.}

$\mathrm{H}_{0}(\mathrm{Me} 1=\mathrm{Me} 2)$ : The productive project "Styles" does not significantly influence the achievement of the abilities of simple hairstyles in students.

$\mathrm{H}_{1}(\mathrm{Me} 1 \neq$ me 2$)$ The productive project "Styles" has a significant influence on the achievement of the abilities of simple hairstyles in students

\section{Table 7}

Wilcoxon signed rank test to test the specific hypothesis according to rank and contrast statistics

\begin{tabular}{|c|c|c|c|c|c|c|}
\hline & $\mathrm{N}$ & $\begin{array}{l}\text { Average } \\
\text { range }\end{array}$ & $\begin{array}{l}\text { Sum of } \\
\text { ranges }\end{array}$ & \multicolumn{2}{|c|}{ Contrast statistics } \\
\hline \multirow[t]{4}{*}{$\begin{array}{l}\text { Pre Simple hairstyles - } \\
\text { Post Simple hairstyles }\end{array}$} & Negative ranges & $3^{\mathrm{a}}$ & 4,00 & 12,00 & $\begin{array}{r}\mathrm{Z}= \\
\mathrm{P} \text { value }=\end{array}$ & $\begin{array}{r}-2,183 \\
, 029\end{array}$ \\
\hline & Positive ranges & $9^{\mathrm{b}}$ & 7,33 & 66,00 & & \\
\hline & Ties & $3^{\mathrm{c}}$ & & & & \\
\hline & Total & 15 & & & & \\
\hline \multicolumn{5}{|c|}{ a. Simple hairstyles pre $<$ Simple hairstyles post } & & \\
\hline \multicolumn{5}{|c|}{ b. Simple hairstyles pre > Simple hairstyles post } & & \\
\hline \multicolumn{5}{|c|}{ c. Simple hairstyles pre $=$ Simple hairstyles post } & & \\
\hline
\end{tabular}


It is observed that after applying the productive project, the students obtained positive advances in the achievement of the abilities of simple hairstyles according to the positive ranges (9) with respect to the three negatives and three ties. Likewise, the value of the statistic $\mathrm{Z}=-2.183<1.96$ and whose $\mathrm{p}$ value $=$ $0.029<0.05$, confirm that there are statistically significant differences between the pre-test and posttest data where they obtained better levels of achievement. Also, observe in the figure, an increase in the median of the post-test data compared to the pretest. Consequently: The "Styles" production project has a significant influence on the achievement of the capabilities of simple hairstyles.

\section{Specific Hypothesis Contrast 2.}

$\mathrm{H}_{0}(\mathrm{Me} 1=\mathrm{Me} 2)$ : The "Styles" production project does not significantly influence the achievement of the styling capabilities.

$\mathrm{H}_{1}(\mathrm{Me} 1 \neq \mathrm{me} 2)$ The "Styles" production project has a significant influence on the achievement of stylized hairstyle capabilities.

\section{Table 8}

Wilcoxon signed rank test to test the general hypothesis according to rank and contrast statistics

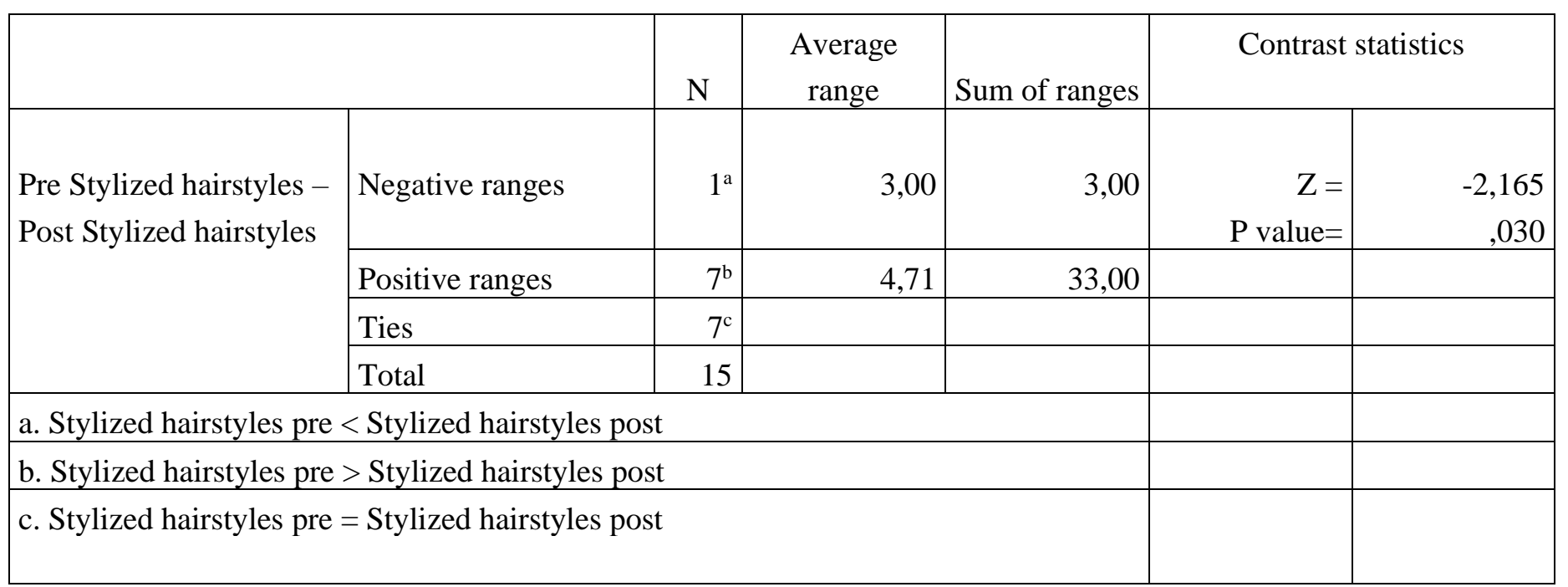

After applying the productive project, the 15 students obtained positive advances in the achievement of the abilities of stylized hairstyles according to the positive ranges (7) with respect to a single negative and seven ties. Likewise, the value of the $\mathrm{Z}$ statistic $=-2.165$ $<1.96$ and whose $\mathrm{p}$ value $=0.030<0.05$, confirm that there are statistically significant differences between the pre-test and post-test data where better levels of achievement were obtained. Also, an increase in the median of the post-test data compared to the pre-test is evidenced in the figure.
Consequently: The "Styles" production project has a significant influence on the achievement of the styling capabilities.

\section{Specific Hypothesis Contrast 3.}

$\mathrm{H}_{0}(\mathrm{Me} 1=\mathrm{Me} 2)$ : The "Styles" production project does not significantly influence the achievement of brushing capabilities.

$\mathrm{H}_{1}(\mathrm{Me} 1 \neq \mathrm{me} 2)$ The "Styles" production project has a significant influence on the achievement of brushing hair capabilities. 
Table 9.

Wilcoxon signed rank test to test the specific

hypothesis according to rank and contrast statistics

\begin{tabular}{|c|c|c|c|c|c|c|}
\hline & & & Average & Sum of & Contrast & \\
\hline $\begin{array}{l}\text { Pre Brushed hairstyles - } \\
\text { Post Brushed hairstyles }\end{array}$ & Negative ranges & $2^{\mathrm{a}}$ & 5,50 & 11,00 & $\begin{array}{r}\mathrm{Z}= \\
\mathrm{P} \text { value}=\end{array}$ & $\begin{array}{r}-2,546 \\
, 011 \\
\end{array}$ \\
\hline & Positive ranges & $11^{\mathrm{b}}$ & 7,27 & 80,00 & & \\
\hline & Ties & $2^{c}$ & & & & \\
\hline & Total & 15 & & & & \\
\hline a. Brushed hairstyles pr & $<$ Brushed hairst & & & & & \\
\hline b. Brushed hairstyles pr & $>$ Brushed hairst & & & & & \\
\hline c. Brushed hairstyles pr & $=$ Brushed hair & & & & & \\
\hline
\end{tabular}

It is observed that after applying the productive project; The 15 students obtained positive advances in the achievement of the skills of brushing hair according to the positive ranges (11) with respect to the two negatives and two ties. Likewise, the value of the $\mathrm{Z}$ statistic $=-2.546<1.96$ and whose $\mathrm{p}$ value $=$ $0.011<0.05$ confirm that there are statistically significant differences between the pre-test and posttest data where they obtained better levels of achievement. Also, an increase in the median of the post-test data compared to the pre-test is observed in the figure. Consequently: The "Styles" production project has a significant influence on the achievement of brushing styling capabilities.

\section{CONCLUSIONS}

First: It was determined that the "Styles" productive project had a significant influence of $60 \%$ in the achievement of personal aesthetic abilities of the Hairstyles Module of the CETPRO students Jesús Oropeza Chonta, SJL 2020, with $\mathrm{p}=0.017<0.05$ having significant advances in 10 female students in the sample. (Model)

Second: It was determined that the productive project "Styles" had a significant influence of $53.3 \%$ in the achievement of the abilities of simple hairstyles of the CETPRO students with a $\mathrm{p}=0.029<0.05$, having significant progress in 9 female students of the sample.

Third: It was determined that the productive project "Styles" has a significant influence of $53.3 \%$ in the achievement of the stylized hairstyles capabilities of the CETPRO students with a $p=0.030<0.05$, having significant progress in 7 female students of the sample.

Fourth: It was determined that the "Styles" productive project has a significant influence of $66.7 \%$ in the achievement of the brushing hair abilities of the CETPRO 
students with a $\mathrm{p}=0.011<0.05$, having significant progress in 11 students of the shows.

\section{REFERENCES}

Altamirano, L. O. (2019). Estrategias de emprendimiento productivo y procesos de enseñanza-aprendizaje técnico con adolescentes Centro de Acogida Féliz Méndez Arcos ciudad de la Paz. [Tesis de grado. Universidad Mayor de San Andrés. La Paz, Bolivia]. https://bit.ly/3gGoGdI

Cazau, P. (2006). Introducción a la investigación en ciencias sociales $\left(3^{\mathrm{a}}\right.$ ed.). Buenos Aires. https://bit.ly/3orV4U7

Cercado, D. E. \& Pazos, E. M. (2019). The proactive entrepreneur in productive technical training Bachelor's [thesis, Universidad de Guayaquil Facultad de Filosofía, Letras y Ciencias de la Educación].

http://repositorio.ug.edu.ec/handle/redug/4475 0

Concytec (2019). Reglamento de Calificación, clasificación y registro de los investigadores del SINACYT", https://bit.ly/3qTUPUa

Cortés, G. (2020). El proyecto productivo como estrategia pedagógica para fortalecer las competencias en emprendimiento de los estudiantes de la media vocacional del Instituto Técnico de Sabana de Torres. [Universidad Autónoma de Bucaramanga. Colombia. Tesis de Maestría]. https://bit.ly/3nevemx

Decreto Supremo N$^{\circ} 022-2004-E D$. Reglamento de Educación Técnico Productivo. https://bit.ly/3qR3S8k

www.psychologyandeducation.net
Guzmán, C. \& Dianderas, G. C. (2016). Aplicación del método de proyectos productivos como estrategia didáctica para mejorar las competencias emprendedoras en el CETPRO Interamericano de la ciudad de Arequipa. [Tesis de la Universidad Nacional de San Agustín de Arequipa, Perú].

Hernández, R., Fernández, C. \& Baptista, P. (2014). Metodología de la investigación ( $\left.6^{a} \mathrm{ed}\right)$. https://www.uca.ac.cr/wpcontent/uploads/2017/10/Investigacion.pdf

INEI (2017). Encuesta Nacional de Hogares. https://bit.ly/3nePzIr

Kerlinger, F.N. (1988). Investigación del comportamiento. México: Interamericana.

Lavado, M. H. (2018). Nivel de Capacidades Emprendedoras de los estudiantes del ciclo básico de la especialidad de Industria Textil y del Vestido del CETPRO "Madre India" de Chimbote, 2017. Tesis. Universidad San Pedro. Chimbote - Perú.

Ley 28044 (2003). Ley General de Educación. https://bit.ly/2KnXmFm

Mantero, E. (2020). Efectos laborales de la pandemia por la COVID-19 en el Perú. Incertidumbre y desafios. Revista Actualidad Laboral https://bit.ly/37a1T7c

Mendoza, L. A. \& Reyes, M. S. (2019). Control de calidad en los proyectos productivos $y$ enseñanza-aprendizaje de estudiantes de industria Alimentaria en el CETPRO Santísima Trinidad - Nuevo Chimbote 2018.[Tesis. Universidad Nacional de Huancavelica. Perú]. 
Minedu (2020). RVM N087-2020-MINEDU. Norma que aprueba las orientaciones para el desarrollo del servicio educativo en los centros de educación técnico-productiva, en el marco de la emergencia sanitaria por covid-19. https://bit.ly/3gDMEGK

MInedu (2019). DS N 004-2019-MINEDU. Reforma de la Educación Técnica-Productiva. https://bit.ly/37adpiW

Minedu (2009). Orientaciones metodológicas para la práctica pre-profesional. Educación TécnicaProductiva. https://bit.ly/2JPHefw

Moreno, D. \& Carrillo, J. (2019). Normas APA 7.a edición. Guía de citación y referenciación. Esta Es Una Publicación de La Coordinación Editorial de La Universidad Central, Basada En La Reciente Publicación de La Séptima Edición Del Publication Manual of the American Psychological Association, 25. https://bit.1y/3n8SmCO

Moreno, D. \& Carrillo, J. (2019). Normas APA 7a. Guía de citación y referenciación. Universidad Central, Bogotá $\quad-\quad$ Colombia. https://bit.ly/37Vwdl2

Naciones Unidas. (2015). La Agenda 2030 y los Objetivos de Desarrollo Sostenible. In Publicación de las Naciones Unidas/Cepal. https://bit.ly/3gGace0

OEI (2010). Metas Educativas 2021 - La educación que queremos para la generación de los bicentenarios. Madrid, España. https://bit.ly/3oMQJeo

Rafael, A. (2008). Desarrollo Cognitivo : Las Teorías de Piaget y de Vygotsky. Master En Paidopsiquiatría. Bienio 07-08, I, 29. https://bit.ly/379kPTr
Resolución Directoral Nº920-2008-ED. Resolución que aprueba el "Diseño Curricular Básico de la Educación Técnico-Productiva: ciclo medio". Dirección de Educación Superior y Técnico Profesional del Ministerio de Educación. Perú.

Resolución Directoral N588-2006-ED. Diseño Curricular Básico para la Educación TécnicoProductiva: ciclo básico. https://bit.ly/3mhr0cq RVM.N¹78-2018-MINEDU. Aprueba el Catálogo Nacional de la Oferta Formativa de la Educación Tecnológica y Técnico-Productiva. https://bit.ly/3nfGOh1

Sánchez, H., Reyes, C. \& Mejía, K. (2018). Manual de términos e investigación científica, tecnológica y humanística. Universidad Ricardo Palma. Lima - Perú. https://bit.ly/3qO1H5f

Sánchez, J. C., Brizeida, W. A. \& Florez, J. L. (2017). Entrepreneurial Education: State of the Art. Propósitos y Representaciones, 5(2), 401473. https://bit.ly/3n8ACHL

Tobón, S. (2008). La formacin basada en competencias en la educación superior: el enfoque complejo. Universidad Autnoma de Guadalajara. https://n9.cl/phb5q

Tomaselli, A. (2018). La educación técnica en el Ecuador: el perfil de sus usuarios y sus efectos en la inclusión laboral y productiva. https://bit.ly/3n8ACaJ

UCV (2020). Guía de elaboración de productos observables. Universidad César Vallejo. Vicerrectorado de investigación.

UCV (2016). Guía de Aprendizaje: Diseño y Desarrollo del Proyecto de Investigación. Universidad César Vallejo.

Unesco (2016). Declaración de Incheon y Marco de Acción para la realización del Objetivo de 5752 


\section{Desarrollo $\quad$ Sostenible \\ https://bit.ly/37X2Yyb}

Ventura, G. D. (2018). El uso del método de proyectos educativos y la formación técnica de los estudiantes del módulo elaboración de productos de pastelería del CETPRO República de Chile. [Tesis de grado. Universidad Nacional de Educación Enrique Guzmán y Valle. Lima-Perú].

Ortega, F. (2011). Trauma cultura e historia: reflexiones interdisciplinarias para el nuevo milenio. Bogotá Universidad Nacional: centro de estudios sociales. CES.

Ramón, J. (2010). Formación de competencias para salir de la pobreza en modelos educativos rurales. Buenos Aires: Consejo Latinoamericano de Ciencias Sociales CLACSO.

Muller, R. (2011) Manual para la presentación de proyectos productivos sostenibles, Tercera edición Peru - Lima

Cabanillas, C. (2017) Programa basado en habilidades gerenciales para mejorar la capacidad de elaboración de proyectos productivos en la I.E $\mathrm{N}^{\circ} 81628$ del caserío san pedro http://repositorio.upao.edu.pe/handle/upaorep/3637

Mendoza, G. (2013) Proyectos productivos y el aprendizaje significativo de los alumnos de la especialidad Mecánica de Producción de la facultad de Tecnología de la Universidad Nacional de Educación Enrique Guzmán y Valle.

Araque, A. (2010) Proyectos Educativos -

Productivos como estrategia metodológica para la
Integración de la Escuela con la Comunidad, Venezuela

Jose Eduardo, C. (2016) Proyectos pedagógicos productivos y emprendimiento en la juventud ruralColombia

file:///C:/Users/Personal/Downloads/Dialnet-

ProyectosPedagogicosProductivosYEmprendimientoE nLa-6416751.pdf

Palomino, M. (2016) "Los Proyectos Productivos y su relación en el desarrollo de competencias en los estudiantes"-Lima Perú

Huiracocha, E. (2019) "Modelo De Gestión Estatal Para La Implementación De Proyectos Productivos En Instituciones Educativas Del Distrito De Corani, Provincia De Carabaya, Región Puno" - Lima - Perú

Mendoza, P. (2018) Planificación de proyectos productivos para mejorar los aprendizajes Lima - Perú http://hdl.handle.net/20.500.12404/10882

Cenich, G. (2005) Propuesta de aprendizaje basado en proyecto y trabajo colaborativo: experiencia de un curso en línea - Argentina-Buenos Aires

https://www.redalyc.org/pdf/155/15507204.pdf

Maldonado, M. (2008) Aprendizaje Basado En Proyectos Colaborativos. Una experiencia en educación $\quad$ Venezuela $\quad-\quad$ Caracas https://www.redalyc.org/articulo.oa?id=7611171600

Garcia, J. (2011) Educational Model Based In Competenciy: Importance And Necessity

Akhyar, Muhammad. (2010). A model of vocational competency assesment of industrial engineering students of Vocational Hig Schools 2011, 
www.journal.uny.ac.id/index,php/joe/article/view/193/ 94

Aguerrondo, Inés. (2009) IBE Working Papers on Curriculum Issues $\mathrm{N}^{\circ}$ 8. UNESCO - Ginebra Suiza

Chaston, Ian; Badger, Beryl; Sadler-Smith, Eugene. (2000). Organizational learning style and competences. A comparative investigation of relationship and transactionally orientated small UK manufacturing firms. European Journal of Marketing

Ysaza, L. (2012) Attitudes - Styles of education: Relation with the academic performance - Colombia https://www.redalyc.org/

Henao, G. (2012) Attitudes - Styles of education: Relation with the academic performance - Colombia https://www.redalyc.org/

Schachter, S., Ellertson, J., McBride, D. \& Gregory, D. 1951. An experimental study of cohesiveness and productivity. Human Relations, 4, 229 - 238.

Agarwal, R., Tannru, M. \& Dacruz, M. 1992. Knowledge-based support for combining qualitative and quantitative judments in resource allocation decisions. Journal of Management Information Systems, 9 (1), 165-184.

Alderfer, C.P. 1987. An intergroup perspective on group dynamics. En J.W. Lorsch (ed.): Handbook of Organizational Behavior (pp. 190- 222). Englewood Cliffs: Prentice Hall

Andersen, E. 2010. Are We Getting Any Better? Comparing Project Management in the Years 2000 and 2008. Project Management Journal, 41 (4): 04-16.
Ashforth, B. E. \& Mael, F. 1989. Social identity theory and the organization. Academy of Management Review, 14(1), 20-39.

Nallusamy, S., Kumar, V., Yadav, V. I. V. E. K., Prasad, U. K., \& Suman, S. K. (2018). Implementation of total productive maintenance to enhance the overall equipment effectiveness in medium scale industries. Int. J. Mech. Prod. Eng. Res. Dev, 8, 10271038.

Atkinson, R. 1999. Project Management: Cost, time and quality, two best guesses and a phenomenon, it's time to accept other criteria. International Journal of Project Management, 17(1), 337-342.

Bredillet, C. N. 2008. Mapping the Dynamics of the Project Management Field: Project Management in Action (Part 1). From Editor, Project Management Journal,: pp. 2-4

Cairncross,F. 2002. The Company of the Future. Cambridge, MA: Harvard Business School Press.

Chiocchio, F. 2004. Successful project completion: Is being "on time" and "on budget" necessary and sufficient?. Canadian Psychology, 42 (2a): 21

Chhabra, J. A. T. I. N. D. E. R., \& Tripathi, B. R. A. J. E. S. H. (2014). Value engineering: a vital tool for improving cost \& productivity. International Journal of Industrial Engineering and Technology (IJIET), 4(6), $1-10$.

Christensen, C., \& Raynor, M.E. 2003. The innovator's solution Creating and Sustaining Successful Growth. Boston: Harvard Business School Press. 
Cleland, D.I. \& Ireland, L. 2002. Project Management: Strategic Design and Implementation (4th ed. Vol. 1). New York: McGraw-Hill.

Zeb-Obipi, I. S. A. A. C. (2015). Corporate productivity performance: A harmonist framework. International Journal of Business and General Management, 4 (1), 19, 28.

Conlon, D.E., \& Garland, H. 1993. The role of project completion information in resource allocation decision. Academy of Management Journal, 36: 402-413.

Cooper, R.G. 1994. Third-Generation new product processes. Journal of Product Innovation Management, 11,3-14.

Cook, M.S. 2001. Real-world Monte Carlo Analysis. Proceeding of PMI Annual Seminars and Symposium, Nashville, TN.

Osa, I. G., \& Amos, I. O. (2014). The impact of organizational commitment on employees productivity: a case study of nigeria brewery, PLC. International Journal of Research in Business Management, 2(9), 107-122.

Doosje, B., Spears, R., \& Ellemers, N. 2002. Social identity as both cause and effect: The development of group identification in response to anticipated and actual changes in the intergroup status hierarchy. British Journal of Social Psychology, 41(1), 57-76.
Durso, F. T., Reardon, R., \& Jolly, E. J. 1985, Selfnonselfsegregation and reality monitoring, Journal of Personality and Social Psychology, 48: 447-455.

BHATIA, K. Library \& Information Officer, National Institute of Occupational Health, Meghaninagar, Ahmadabad, India.

Ellemers, N., Haslam, A., Platow, M. J., \& van Knippenberg, D. 2003. Social Identity at work: developments, debates and directions. In A. Haslam \& D. van Knippenberg \& M. J. Platow \& N. Ellmers (Eds.), Social Identity at work. Developing theory for organizational practice. (pp. 3-28.). New York: Psychology Press

SALEEM, M., \& PERVEEN, N. ORGANIZATIONAL CLIMATE AND ITS IMPACT, ON FIRM FINANCIAL PERFORMANCE.

Gareis, R. \& Huemann, M. 2007. Maturity models for the projects oriented company. In J.R. Turner (Ed), The Gower Handbook of Project Management. Aldershot: Gower. 